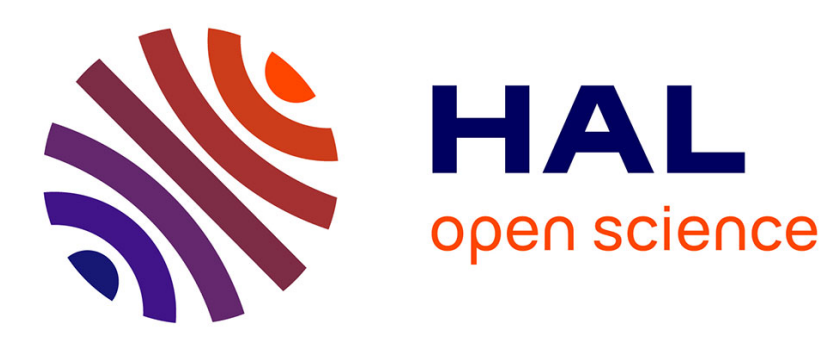

\title{
Bank opacity, intermediation cost and globalization: Evidence from a sample of publicly traded banks in Asia
} Wahyoe Soedarmono, Amine Tarazi

\section{To cite this version:}

Wahyoe Soedarmono, Amine Tarazi. Bank opacity, intermediation cost and globalization: Evidence from a sample of publicly traded banks in Asia. Journal of Asian Economics, 2013, 29, pp.91 - 100. 10.1016/j.asieco.2013.09.003 . hal-01098719

\section{HAL Id: hal-01098719 https://hal.science/hal-01098719}

Submitted on 28 Dec 2014

HAL is a multi-disciplinary open access archive for the deposit and dissemination of scientific research documents, whether they are published or not. The documents may come from teaching and research institutions in France or abroad, or from public or private research centers.
L'archive ouverte pluridisciplinaire HAL, est destinée au dépôt et à la diffusion de documents scientifiques de niveau recherche, publiés ou non, émanant des établissements d'enseignement et de recherche français ou étrangers, des laboratoires publics ou privés. 


\title{
Bank opacity, intermediation cost and globalization:
}

\section{Evidence from a sample of publicly traded banks in Asia}

\author{
Wahyoe Soedarmono ${ }^{1}$ \\ Universitas Siswa Bangsa Internasional, Faculty of Business / Sampoerna School of Business \\ Mulia Business Park, Building D, Jl. MT Haryono Kav 58 - 60, Jakarta 12780, Indonesia
}

\author{
Amine Tarazi \\ Universite de Limoges, LAPE \\ 5 rue Felix Eboue BP.3127, 87031 Limoges, France
}

\begin{abstract}
This paper examines the relationship between opacity and the cost of intermediation in Asian banks. Using a sample of publicly traded commercial banks from 2002 to 2008, our empirical results show that higher opacity is associated with a lower intermediation cost in banking. Hence, bank managers in their efforts to overcome asymmetric information issues and to improve transparency tend to offset the higher cost of acquiring and disclosing information by increasing the cost of intermediation for entrepreneurs. Moreover, a deeper look at the country level indicates that the negative link between opacity and the cost of intermediation is reversed as globalization increases. Greater globalization therefore outweighs managerial entrenchment behavior to preserve bank opacity. Our findings highlight that bank opacity issues are even more costly in countries with higher globalization.
\end{abstract}

Keywords: Bank opacity, financial intermediation, globalization, Asia

JEL Classification: G21, G28

\footnotetext{
${ }^{1}$ Corresponding author. Tel: (+62-21) 7942340. Email: wahyoe.soedarmono@ssb.ac.id (W. Soedarmono), amine.tarazi@unilim.fr (A. Tarazi).
} 


\section{Introduction}

Financial crises in both developing and developed countries during the last two decades have highlighted the shortcomings of uncontrolled financial liberalization. On the one hand, financial liberalization has led to stronger financial development and has therefore reduced the opaqueness of bank loans, since the availability of credit information regarding borrowers' financial health has increased (Rajan, 2005). Moreover, banks are now allowed to engage in securitization that enables them to accurately price their credit risk, while the development of structured products such as collateralized loan obligations also enables investors and rating agencies to price bank loans. On the other hand, financial development could also have created opportunities for bank managers to engage in more opaque activities, in order to substitute costs of monitoring to reduce asymmetric information related to bank loans (Wagner, 2007).

For instance, in the case of the US, the end of the Glass-Steagall Act in 1999 has brought US banks to engage in off-balance-sheet activities. Wagner (2007) points out that the unused commitments of US commercial banks as a share of total assets have increased from $37 \%$ to $64 \%$ over the last two decades. The share of long-term loans in total loans in US banks has also increased from $15 \%$ to $25 \%$ in the same period ${ }^{2}$. In parallel, US banks have experienced a substantial increase in non-interest income as documented by Stiroh (2004) with a share of noninterest income in total income growing rapidly from 19\% in 1980 to $43 \%$ in 2004.

In countries with stricter restrictions on off-balance-sheet activities, it is rather difficult for banks to substitute their costs of acquiring and disclosing information on bank assets by engaging in off-balance-sheet activities. Such banks can thus offset their costs by increasing the intermediation cost (higher loan rates charged to borrowers and/or lower deposit rates). Meanwhile, whether or not promoting greater transparency has an impact on the intermediation cost in banking is an important issue that has, to our knowledge, not been examined before. This paper fills this gap in the literature by focusing on Asian countries where restrictions on off-

\footnotetext{
${ }^{2}$ Long-term loans are typically more opaque than short-term loans, because borrowers' financial health is rather difficult to measure over a longer horizon (Wagner, 2007). Some studies also highlight that an overall increase in bank opacity typically occurs in the long-run period. Morgan (2002) documents that the opacity of US banks relatively to that of non-bank institutions in the US has increased from $92 \%$ in 1983 to 109\% in 1993. For European banks, Iannotta (2004) also points out that their opacity relatively to non-bank institutions has increased from $82 \%$ in 1993 to $100 \%$ in 2003.
} 
balance-sheet activities are still high and the share of non-interest income activities rather limited (Agusman et al., 2008; Adams, 2008).

Specifically, we aim to test whether bank managers' efforts to reduce opacity may be beneficial or detrimental for financial intermediation in Asian countries. Moreover, we also extend our analysis to examine whether the link between bank opacity and the intermediation cost is dependent on the level of institutional development. Indeed, institutional development has impacted the extent to which Asian countries have suffered from the 1997 Asian crisis which in turn has affected intermediation activities in those countries. For instance, Furman and Stiglitz (1998) document that Asian countries with weaker institutional development, such as Indonesia and Thailand, were severely affected by the 1997 Asian crisis.

Our focus on the link between bank opacity and the intermediation cost in Asian countries is motivated by the following reasons. It is generally admitted that asymmetric information has contributed to exacerbate financial instability in Asia which triggered the 1997 Asian crisis (Sau, 2003). In order to prevent financial crises in the future, reducing asymmetric information is therefore necessary. Surprisingly, previous literature has not examined the issue of whether reducing asymmetric information or promoting information transparency in banking has an impact on real economic activities stemming from movements in bank intermediation cost.

Meanwhile, the banking sector remains a major source of finance for firms in Asian countries and therefore examining the ways to promote intermediation is essential in fostering economic growth in Asian countries (Adams, 2008). Yet, Asian banking has developed rapidly since the end of the 1997 crisis. Cross-border mergers and acquisitions involving Asian banks have increased from US\$ 2.5 billion during 1991-1995 to US\$ 65 billion during 2001-2005 (Domanski, 2005; Moshirian, 2008). As the financial sector has rapidly grown in Asian countries, assessing the link between bank opacity and the intermediation cost has become an important issue because financial development exacerbates bank managers' incentives to preserve the opacity of bank assets (Wagner, 2007). Consequently, it is important to examine whether such managerial entrenchment leads to a higher intermediation cost.

The rest of this paper is structured as follows. Section 2 presents our research focus and relates it to previous literature. Section 3 describes the data, variables and methodology used in 
this study. Section 4 discusses empirical findings and provides some robustness checks, while Section 5 concludes the paper.

\section{Related literature and research focus}

The role of the banking sector in supporting economic growth has been widely explored and this issue is still broadly debated. Bencivenga and Smith (1991) are the first to demonstrate that the presence of banks as financial intermediaries enhances long-run economic growth because banks can optimize depositors' funds to boost long-term savings and investments. In contrast, a large number of papers also indicate the presence of threshold effects. Hence, the link between financial intermediation and development is not necessarily positive (e.g. Augier and Soedarmono, 2011; Deidda and Fattouh, 2002; Bose and Cothren, 1996 \& 1997) $)^{3}$.

As a matter of fact, the presence of asymmetric information is one of the factors that make the link between finance and development rather ambiguous. The financial intermediation approach developed by Diamond (1984) shows that bank loans are opaque and hence, the cost of monitoring to reduce asymmetric information in bank loans can affect financial intermediation via its impact on the lending rate. In a similar vein, Bose and Cothren (1997) show that banking development can enhance capital accumulation and long-run growth, when the cost of acquiring information from screening activities falls below a threshold level. This result can be further interpreted that the expertise of banks in overcoming asymmetric information plays a critical role in making the economy move toward a credit screening equilibrium rather than a credit rationing equilibrium.

The empirical literature shows that the extent of asymmetric information strongly affects the development and the stability of the banking sector. Tsai et al (2011) show that banks are more likely to expand operations in countries with a credit reporting bureau, where shared credit reports are of better quality in terms of timeliness, accuracy and completeness. Banks are thus likely to expand in countries with lower asymmetric information. In parallel, the stock market also suffers from asymmetric information between lenders and borrowers. Hence, financial liberalization that fosters stock market development too rapidly can exacerbate asymmetric

\footnotetext{
${ }^{3}$ See Levine (2005) for a comprehensive literature review on the finance-growth nexus.
} 
information and deteriorate bank stability ending up in banking crises (Bhide, 1993; DemirgüçKunt and Detagriache, 1999).

From these studies, it is indeed clear that the presence of asymmetric information plays a significant role in affecting financial development and stability. However, there is no previous study that provides empirical evidence on the impact of asymmetric information in banking on economic activities in particular. The present paper attempts to contribute in this direction. Specifically, we build on the work of Bose and Cothren (1997) and Wagner (2007) to examine the link between asymmetric information and the cost of intermediation in banking.

According to Bose and Cothren (1997), the extent to which bank assets are opaque determines the cost of acquiring information which in turn determines capital stock accumulation. In the present paper, instead of focusing on capital stock accumulation and economic growth, we examine whether bank managers in their efforts to overcome asymmetric information, tend to offset higher cost of acquiring and disclosing information by increasing the intermediation cost for entrepreneurs. In other words, we test the link between bank opacity and the intermediation cost. As further contributions, we also examine whether the link between bank opacity and intermediation cost is country-specific.

Poghosyan (2013) highlights that institutional development plays a crucial role in affecting the cost of bank intermediation. Lower institutional quality is found to increase the intermediation cost. Building on this work, we test whether institutional development matters in affecting the link between opacity and the intermediation cost in banking. Given that our study focuses on the role of informational transparency, we therefore emphasize on institutional development related to the degree of countries' openness that integrates information-sharing activities. We use the globalization index developed by Dreher et al. (2008) as a proxy of institutional development that contains a measure of economic globalization, political globalization, and social globalization which include transparency in terms of information flows. Dreher et al. (2008) empirically show that the overall index of globalization is indeed positively associated with economic growth. 


\section{Data, variables and methodology}

\subsection{Data sources}

In order to assess the link between opacity and the intermediation cost in banking, we use several sources of data. Bank-level data are retrieved from BankScope Fitch IBCA. Only publicly traded banks (i.e. listed on a stock exchange) are considered in this study because our framework requires the use of data on bank stock prices. Due to such restrictions, our sample consists of an unbalanced panel of 253 listed commercial banks for the 2002-2008 period that operate in 13 Asian developed and developing countries ${ }^{4}$. These countries include China (14), Hong Kong (6), Japan (87), South Korea (7), Taiwan (12), Indonesia (25), Malaysia (4), Philippines (12), Singapore (3), Thailand (11), Pakistan (23), India (40, and Sri Lanka (9).

We consider daily stock price data for each bank in our sample and also the daily global market indices at the country level. Such market data come from Thomson Datastream International. For deeper insights on whether the link between opacity and the intermediation cost in banking depends on the quality of institutions, we also retrieve the index of globalization $(G L O B A L)$ from Dreher et al (2008) as a proxy of institutional development to reflect the degree of openness in various aspects including the economic, social and political dimensions. To construct our macroeconomic control variables, we retrieve data from International Financial Statistics provided by the International Monetary Fund, except for the ratio of bank concentration (CONC) which is retrieved from Beck and Demirgüç-Kunt (2009).

\subsection{Bank intermediation cost}

In order to measure the bank intermediation cost, we consider the ratio of net interest income to total assets or net interest margin (NIM). NIM is widely used as a proxy of bank intermediation cost in the previous literature (e.g. Demirgüç-Kunt et al, 2004; Demirgüç-Kunt and Huizinga, 1999; Dabla-Norris and Floerkeimer, 2007; Naceur and Kandil, 2009). Banks' net interest margin can be considered as a price markup to offset higher costs related to banking operations in lending, monitoring and deposit activities. Higher net interest margin implies that banks are likely to experience a higher intermediation cost which they in turn transfer to their

\footnotetext{
${ }^{4}$ The choice of countries included in our sample builds on Soedarmono et al. (2013), and Agusman et al. (2008) who study Asian banks, except that we add Japan and China.The values in parentheses are the number of banks.
} 
customers (higher loan rates for borrowers and/or lower rates for depositors). Following Demirgüç-Kunt et al. (2004), we also consider the ratio of overhead cost to total assets (OVER) as an alternative proxy of the bank intermediation cost.

Some papers consider that higher net interest margins merely reflect higher profitability in banking instead of higher intermediation cost charged to borrowers (e.g. Naceur and Kandil, 2009; Naceur and Oman, 2011). For robustness considerations, we build another measure to capture the intermediation cost. More precisely, we consider a net interest margin measure which is adjusted for profitability $(R N I M)$. This measure reflects a markup price that "purely" captures the motivation of bank managers to offset costs of banking operations which are in turn positively associated with the bank's intermediation cost, i.e. the margin charged to borrowers. RNIM is computed using the residual terms of an Ordinary Least Squares (OLS) regression of NIM on both return on assets $(R O A)$ and return on equity $(R O E)^{5}$. Accordingly, RNIM captures movements in the net interest margin that are not influenced by changes in bank profitability. Overall, higher NIM, RNIM and OVER are all associated with a higher intermediation cost in banking.

\subsection{Bank opacity}

We assess the degree of bank opacity using an indicator of bank stock price synchronicity $(S Y N C)$. Previous empirical studies support the use of stock price synchronicity to account for the extent of information reflected in stock prices and hence, determining firms' transparency. Roll (1988) documents that the weak relationship between firms' stock price and market price movements is due to the fact that more firm-specific information can be reflected in individual firms' stock prices. In other words, the relative amounts of firm-specific information incorporated in stock prices determine whether or not individual firms' stock prices move together in the same direction with the stock market index.

If firm-specific environments (e.g. firms' disclosure policies, analyst reports, or institutional factors including property rights protection, the quality of government and legal origin) cause individual firms' stock prices to aggregate more firm-specific information, stock price synchronicity should be lower (Morck et al, 2000; Durnev et al., 2003; Chan and Hameed,

\footnotetext{
${ }^{5} R O A$ is the ratio of net income to total assets, while $R O E$ is the ratio of net income to total equity.
} 
2006; Jin and Myers, 2006; Piotroski and Roustone, 2004). In this case, $R$-squared from a standard market model that reflects a firm's stock return synchronicity should be lower, while firm-specific return variation should be higher. By extension, a firm's transparency tends to be higher in this regard (Jin and Myers, 2006).

Following Chan and Hameed (2006), we compute opacity (SYNC) using stock price synchronicity which is estimated from a standard market model defined as follows:

$$
r_{i j s}=\alpha_{i}+\beta r_{j s}^{m}+\varepsilon_{i s}
$$

From Equation (1), $r_{i j s}$ is the stock return on bank $i$ in country $j$ on day $s$, while $r_{j s}^{m}$ is the daily market return computed on the basis of domestic market indexes in country $j$ on day $s$. Both variables are defined as follows:

$$
\begin{aligned}
& r_{i j s}=\log \left\lfloor\frac{p_{i j s}}{p_{i j s-1}}\right\rfloor \\
& r_{j s}^{m}=\log \left\lfloor\frac{p_{m(j), s}}{p_{m(j), s-1}}\right\rfloor
\end{aligned}
$$

Accordingly, $p_{i j s}$ is the stock price of bank $i$ in country $j$ on day $s$, while $p_{m(j), s}$ is the global market price index in country $j$ on day $s$.

In the next stage, we run regressions from 2002 to 2008 to estimate Equation (1) using the OLS method following Bautista et al (2009). For each year, we eliminate banks with trading days less than $70 \%$ of the total number of trading days per year. As such, we obtain the annual $R^{2}$ from bank stock $i$ in country $j$ at year $t$. Given the bounded nature of $R^{2}$ between zero and one, we then apply a logistic transformation. The degree of bank synchronicity is thus defined as

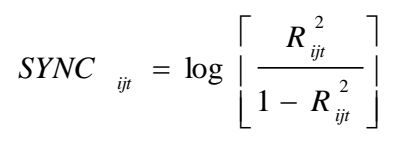

From Equation (2), a higher $R^{2}$ reflects higher bank stock price synchronicity (SYNC), i.e. the stock price predominantly moves in the same direction as the global market index. In such a case, the weaker bank-specific information content can be incorporated in the bank stock price 
and hence, bank-level information disclosure in bank stock prices is also weaker because of stronger opacity problems.

To our best knowledge, prior studies on firm transparency mainly have mainly focused on non-financial firms (e.g. Ball, 2001; Bushman and Smith, 2001; Chan and Hameed, 2006; Gul et al., 2010). Although the need for bank transparency to strengthen market discipline is widely recognized (Flannery, 1998), only Francis et al (2012) have examined the determinants of stock return synchronicity in the banking industry. We hence contribute to the scarce literature lookingat stock price synchronicity to account for opacity in banking..

Nevertheless, several studies also cast doubts on the use of bank stock price synchronicity as a valid measure to assess the extent to which firms are transparent (e.g. Dasgupta et al., 2010; Ashbauh-Skife et al., 2006). As a validity check, we follow Gul et al. (2010) to test whether stock price synchronicity can ascertain the extent to which banks are transparent or opaque. In doing so, we build the following regression model:

$$
\begin{aligned}
\operatorname{MAR}_{i j t}= & \beta_{0}+\beta_{1} N I_{i j t}+\beta_{2} N I * S Y N C_{i j t}+\beta_{3} N I * E Q T A_{i j t} \\
& +\beta_{4} N I * M T B V_{i j t}++ \text { error }
\end{aligned}
$$

$M A R$ is the market-adjusted bank stock return measured by the difference between annualized bank stock returns and annualized capital market returns. NI is the ratio of net income to the market value of equity. EQTA and $M T B V$ represent the ratio of total equity to total assets, and the market-to-book-value ratio, respectively. Meanwhile, $N I^{*} E Q T A$ and $N I^{*} M T B V$ are control variables as used by Gul et al. (2010). To estimate Equation (3), we include both individual and time-fixed effects. $S Y N C$ can be considered as a valid measure of bank opacity when $\beta_{1}$ is positive but $\beta_{2}$ is negative. This suggests that capital markets can attach higher value to earnings, but only in banks with lower synchronicity. As synchronicity becomes higher, the positive link between $N I$ and $M A R$ is reversed. Opacity problems therefore occur because earnings information capitalized into stock prices becomes lower in high-synchronicity banks.

\subsection{Control variables}

To control for other factors that explain movements in the bank intermediation cost, control variables representing both bank-specific and country-specific factors are incorporated in 
the regressions. For bank-specific control variables, we consider the ratio of total equity to total assets (EQTA), the ratio of loan loss provisions to total loans ( $L L P)$, the loan-to-deposit ratio $(L D R)$ and the logarithm of banks' total assets (SIZE). To control for differences in the macroeconomic environment and market structure, we consider three indicators which are the bank concentration ratio measured by the share of the three largest banks' total assets in the banking system's total assets (CR3), the growth rate of real per capita income (GDPG), and the inflation rate $(I N F)$.

Higher EQTA is likely to increase bank net interest margin because of a decline in funding costs, since higher EQTA can reduce bank default risk which in turn decreases funding costs (Demirgüç-Kunt et al, 2004). LLP and LDR are incorporated to account for credit risk and intermediation activities, respectively. Banks with higher credit risk are expected to charge a higher lending rate resulting in a higher intermediation cost. Meanwhile, as higher $L D R$ is associated with more lending activities, higher loan-to-deposit ratio is expected to increase the intermediation cost because banks tend to offset higher monitoring costs related to lending activities. In addition, SIZE is also included to control for "too-big-to-fail" effects that might affect banks' loan pricing behavior. However, the expected sign of the link between SIZE and the intermediation cost is ambiguous. Larger banks could charge lower rates because they do not fear distress. They can also benefit from lower funding cost (lower deposit rates) because of higher confidence from depositors (higher bail-out probability).

With regards to macroeconomic control variables, a higher bank concentration ratio $(C R 3)$ is expected to increase the bank intermediation cost because banks in concentrated markets are able to charge higher lending rates (Demirgüç-Kunt et al., 2004). Moreover, considering economic growth $(G D P G)$, which is standard in the literature is also important in order to reflect business cycle movements. Changes in economic growth are expected to change business opportunities for banks. However, the sign of the link between economic growth and the intermediation cost is unclear, since it depends on banks' expertise in dealing with changes in the business cycle. Finally, we also control for the inflation rate (INF) because a higher inflation rate can lead to a higher bank net interest margin as shown by Huybens and Smith (1999). 


\subsection{Methodology}

Our analysis is conducted in several stages. In the first stage, we compute a measure of bank stock price synchronicity $(S Y N C)$. In the second stage, a validity check is conducted using Equation (3) to ensure that $S Y N C$ can be used to assess the degree of bank opacity. In the next turn, the link between bank opacity and intermediation cost is empirically examined.

Once the general results are obtained, we further examine whether the degree of globalization at the country level alters the link between bank opacity and intermediation cost. For this purpose we interact $S Y N C$ with the index of globalization (GLOBAL) and focus on the coefficient of $S Y N C^{*} G L O B A L$. The index of globalization $(G L O B A L)$ indicates the extent to which countries are open in terms of economic, political and social dimensions that integrate information-sharing activities in those countries. GLOBAL is the overall index of globalization or the KOF Index of Globalization developed by Dreher et al. (2008) which integrates all aspects of globalization, i.e. social, economic and political dimensions of globalization.

In terms of econometric methodology in examining the link between opacity and the intermediation cost in banking, we use a dynamic panel model. Recent studies on the determinants of bank performance recommend the use of dynamic panel data methodology (e.g. Naceur and Kandil, 2009; Naceur and Omran, 2011), since the current intermediation cost can be affected by its past values due to managerial anticipation or learning. Hence, the use of a dynamic panel model is more relevant than a static panel model to capture such possible behavior i.e. to control for a possible autoregressive process in the bank intermediation cost variable. Nevertheless, our concern in this study is more to examine the impact of bank opacity on the intermediation cost rather than the speed of adjustment of the bank intermediation cost.

Accordingly, we test the following models. Equation (4) is to test the impact of bank opacity $(S Y N C)$ on the intermediation cost (COST), while Equation (5) is to test whether such a relationship is dependent on the degree of globalization at the country level, respectively ${ }^{6}$.

$$
\begin{aligned}
\operatorname{COST}_{i j t}= & \beta_{0} \operatorname{COST}_{i j t-1}+\beta_{1} \operatorname{SYNC}_{i j t}+\beta_{2} \operatorname{EQTA}_{i j t}+\beta_{3} \operatorname{LLP}_{i j t}+\beta_{4} L D R_{i j t} \\
& +\beta_{5} \operatorname{SIZE~}_{i j t-1}+\beta_{6} C R 3_{j t}+\beta_{7} G D P G_{j t}+\beta_{8} I N F_{j t}+\text { error }
\end{aligned}
$$

\footnotetext{
${ }^{6}$ COST represents a set of dependent variables that capture the bank intermediation cost. These include NIM, OVER, and RNIM.
} 


$$
\begin{aligned}
& \operatorname{COST} T_{i j t}=\beta_{0} \operatorname{COST}{ }_{i j t-1}+\beta_{1} \operatorname{SYNC}_{i j t}+\beta_{2} \operatorname{SYNC} * G L O B A L_{i j t}+\beta_{3} G L O B A L \quad j i \\
& +\beta_{4} E Q T A_{i j t}+\beta_{5} L L P_{i j t}+\beta_{6} L D R_{i j t}+\beta_{7} S I Z E_{i j t}+\beta_{8} C O N C_{j t} \\
& +\beta_{9} G D P G_{j t}+\beta_{10} I N F_{j t}+\text { error }
\end{aligned}
$$

In estimating all the regressions, we follow Arellano and Bover (1995) and Blundell and Bond (1998) using the two-step generalized method of moments (GMM) estimator or the System GMM. The System GMM is the extension of the Standard GMM developed by Arellano and Bond (1991), where the first-differenced equation is combined with the level equation in order to produce better outputs than the Standard GMM (Baltagi, 2005). This combination is essential, particularly when variables are close to a random walk. In running the System GMM, we also consider finite sample corrections proposed by Windmeijer (2005) to ensure that our estimated coefficients are robust. Since our dynamic panel data models contain an autoregressive variable, we account for the orthogonal deviation transformations of instruments to control for possible bank-level fixed effects. Overall, the System GMM is valid if AR (2) test and Hansen-J test are both insignificant. This indicates that there is no second-order autocorrelation among errors of first-differenced equation, and our identifying restrictions are valid, respectively.

On the whole, all the estimations from Equation (3) to Equation (5) are conducted separately for two different bank samples. The first sample includes all the banks operating in the considered 13 Asian countries. Meanwhile, the second sample excludes, as a robustness check, Japanese banks which dominate our sample, to ensure that our results are not affected by Japanese banks' characteristics.

\section{Empirical results}

In Table 1, we present descriptive statistics for all the variables used in this study. We also impose restrictions to the ratio of total equity to total assets (EQTA) to eliminate possible outliers. Specifically, we eliminate values in EQTA that are lower than zero. Banks with negative EQTA may not fully operate in the market because they may require assistance from bank regulators or the lender of last resort. 
[Insert Table 1 here]

Moreover, Table 2 presents the correlation structures of all the variables used to analyze the link between opacity and intermediation cost in banking. It shows that the independent variables included in Equations (4) and (5) are not strongly correlated and hence, that our regressions do not suffer from multicollinearity issues.

[Insert Table 2 here]

Given that the previous literature cast doubts on the use of bank synchronicity as a measure of bank opacity, we test whether bank stock price synchronicity can be a valid proxy of bank opacity. Table 3 presents the empirical results for Equation (3). The ratio of net income to the market value of equity $(N I)$ has a positive and significant relationship with the marketadjusted return of banks $(M A R)$. Such a relationship is however reversed for $N I * S Y N C$, suggesting that higher $S Y N C$ reduces the likeliness of the market to attach a higher value to bank earnings. In this regard, SYNC reflects the extent to which banks may suffer from opacity problems. These results hold for both the overall bank sample and the non-Japanese bank sample.

[Insert Table 3 here]

To ensure the robustness of our results, we repeat estimations for Equation (3) by replacing $M A R$ with $B S R$ which represents the annualized bank stock return. It appears that higher $N I$ is still associated with higher $B S R$, particularly for low-synchronicity banks. For highsynchronicity banks, the positive relationship between $N I$ and $B S R$ is reversed, supporting the notion that higher synchronicity precludes the incorporation of bank-specific information into bank stock prices. High-synchronicity banks are thus more likely to suffer from opacity problems than low-synchronicity banks. These results remain unaltered when we include or exclude Japanese banks from our estimations. 
From the above discussion, our indicator of bank synchronicity can be considered as a valid proxy to assess the degree of bank opacity. Table 4 then presents our empirical results with regards to the impact of bank opacity on the intermediation cost for the overall bank sample and the sample from which Japanese banks are excluded.

[Insert Table 4 here]

For the overall bank sample, we document that higher bank opacity is associated with a lower intermediation cost measured by NIM or RNIM. Our dynamic panel data models are also valid, given that the AR (2) test and the Hansen-J test are not rejected at least at the 5\% level. These findings still hold when we exclude Japanese banks from our sample. Our findings are therefore consistent with the notion that disclosing and sharing information is costly due to managerial entrenchment effects. Since bank managers tend to preserve the opacity of banks' assets as in Wagner (2007), low-synchronicity (or transparent) banks are more likely to exhibit a higher intermediation cost than high-synchronicity (opaque) banks. Accordingly, the managers of transparent banks tend to offset costs of acquiring and disclosing information by increasing the cost of credit for entrepreneurs due to the entrenchment effect. On the other hand, higher transparency can also reduce the cost of bank deposits because of higher confidence of bank depositors. In this case as well, the cost of intermediation may in turn increase, although the cost of credit does not increase.

When we consider the role of the degree of globalization (GLOBAL), we find that the negative impact of bank opacity on the intermediation cost is more pronounced in countries with lower globalization. As globalization at the country level increases, the negative link between bank opacity and intermediation cost is reversed, especially when we use NIM or OVER as a proxy of the bank intermediation cost as shown in Table 5. The negative coefficient on SYNC is more than outweighed by the positive coefficient on $S Y N C * G L O B A L$ (the absolute value of the coefficient of $S Y N C^{*} G L O B A L$ is higher than the absolute value of the coefficient of $S Y N C$ ). An increase in $S Y N C$ will lead to a decrease in the cost of intermediation if the value taken by GLOBAL is very low, but to an increase in the cost of intermediation for higher values taken by 
$G L O B A L^{7}$. We lose a substantial number of observations in this stage because Dreher et al. (2008) do not provide data on globalization indices for Hong Kong and Taiwan, and our sample incorporates publicly-traded commercial banks from both countries. But in Table 5, our dynamic panel data models remain valid, since AR (2) test and Hansen-J test are not rejected, at least at the $5 \%$ level.

\section{[Insert Table 5 here]}

In countries with greater globalization, bank opacity might increase the cost of intermediation possibly because of the following reasons. Countries with greater globalization have greater openness in terms of economic, political and social dimensions and hence, demand for greater transparency in various aspects tends to be higher. With regards to banking activities, agents from such countries are also likely to require information of better quality and better financial services. Consequently, banks with higher opacity problems in countries with greater globalization tend to face higher demand for transparency which may in turn outweigh bank managerial entrenchment effects to preserve opacity. In turn, the bank intermediation cost might be positively linked with opacity in countries with greater globalization. In order to enhance financial intermediation, efforts to improve bank-level transparency are therefore necessary in such countries.

Furthermore, because bank opacity problems can also exacerbate asymmetric information issues that could possibly lead to financial instability (Sau, 2003), efforts to increase bank-level transparency in countries with lower globalization remain important. However, bank regulators in countries with lower globalization need to deal with managerial entrenchment effects by promoting bank-level transparency because bank managers in such countries tend to offset the cost of acquiring and disclosing information by increasing the cost of intermediation.

In the meantime, most of the control variables fulfill our expected signs. EQTA as the equity-to-asset ratio has a positive impact on the cost of intermediation. This result remains

\footnotetext{
7 The marginal effect of an increase in $S Y N C$ is equal to $\beta_{1}+\beta_{2} G L O B A L_{i j t}$ which for instance in the first equation of table 5 (column 1) is positive for values of GLOBAL higher than $0,28793 / 0,43282=0.66524$. In our sample, GLOBAL ranges from 0.4616 to 0.8915 (see Table 1).
} 
robust whether or not we exclude Japanese banks from our sample. Higher bank credit risk ( $L L P)$ is also found to exacerbate the cost of intermediation in both the overall bank sample and the non-Japanese bank sample. Bank size (SIZE) is also positively associated with a higher intermediation cost for the overall bank sample and the non-Japanese bank sample. With regards to macroeconomic control variables, a higher bank concentration ratio $(C R 3)$ and a higher inflation $(I N F)$ also exacerbate the intermediation cost, while stronger economic growth (GDPG) has a negative impact onit. These results hold whether or not we exclude Japanese banks from the sample.

\section{Additional robustness checks}

Although our empirical results regarding the link between intermediation cost and opacity in banking are robust to different measures of the bank intermediation cost, as well as to different sample definitions that exclude or include Japanese banks, we conduct additional robustness checks to ensure that our results are not biased. First, given that Asian countries differ in terms of the depth of financial markets which may in turn affect the extent to which bank-specific information can be incorporated in bank stock prices, we focus on countries that have similar levels of financial market development. Accordingly, we exclude banks operating in India, Pakistan and Sri Lanka from our sample. Our empirical results remain identical when we ignore these three countries. Higher opacity leads to a lower intermediation cost in banking, but this relationship is reversed as globalization at the country-level increases.

Second, Dreher et al. (2008) do not provide globalization data on Hong Kong and Taiwan and hence, we also exclude banks from these two countries. Our results are unaltered, with higher opacity leading to higher intermediation cost in banking.

Third, as we only consider listed banks in our study, which are more likely to be categorized as large banks in their countries, we exclude SIZE from the control variables as stated from Equation (4) and (5). Using this new specification does not alter our empirical results.

Finally, we exclude the year 2008 to eliminate the possible effects of the 2008 global financial crisis. We thus conduct regressions for Equation (4) and (5) using the 2002-2007 period and still find a negative link between opacity and the intermediation cost. In addition, in 
countries with greater globalization, the negative link between opacity and the intermediation cost in banking is still reversed.

\section{Conclusion}

Using a sample of publicly traded commercial banks in 13 Asian countries, this paper examines how bank opacity is valued by bank managers through its relationship with the cost of bank intermediation. Our empirical results reveal that higher opacity is associated with lower intermediation cost in banking. This result provides empirical support for the theoretical work by Wagner (2007) who argues that bank opacity is positively valued by bank managers who tend to preserve it. Similarly, we also provide empirical support for the theoretical model built by Bose and Cothern (1997) who find that bank managers, in their efforts to alleviate asymmetric information and enhance transparency, tend to offset the cost of acquiring and disclosing information by increasing monitoring costs that in turn hinders economic growth.

Nevertheless, the negative link between bank opacity and the intermediation cost is also conditional on the degree of globalization at the country level. In countries with greater globalization, the negative link between bank opacity and the intermediation cost is reversed. Greater globalization therefore seems to outweigh the managerial entrenchment to preserve bank opacity. As such, higher bank opacity leads to a higher bank intermediation cost in countries with greater globalization. These findings show that managerial entrenchment effects that lead to greater incentives for bank managers to preserve bank opacity are more likely to occur in countries with lower globalization.

On the whole, our findings highlight the importance of bank transparency to promote better financial intermediation, particularly in countries with greater globalization. Efforts to enhance bank transparency in less globalized countries is also important. However, bank regulators in less globalized countries need to consider mechanisms to overcome bank managerial entrenchment because bank managers' efforts to enhance bank-level transparency can exacerbate the intermediation cost. 


\section{References}

Adams, C., 2008. Emerging East Asian banking system: Ten years after the 1997/98 crisis. ADB Working Paper Series on Regional Economic Integration 16.

Agusman, A., Monroe, G.S., Gasbarro, D., Zumwalt, J.K., 2008. Accounting and capital market measures of risk: Evidence from Asian banks during 1998-2003. Journal of Banking and Finance 32(4), 480-488.

Arellano, M., Bover, O., 1995. Another look at the instrumental variable estimation of errorcomponent models. Journal of Econometrics 68, 29-51.

Arellano, M., Bond, S., 1991. Some tests of specification for panel data: Monte Carlo evidence and an application to employment equations. Reviews of Economic Studies 58, 277-297.

Ashbaugh-Skife, H., Gassen, J., LaFond, R., 2006. Does stock price synchronicity represent firm-specific information? The international evidence. MIT Sloan Research Paper 4551-05.

Augier, L., Soedarmono, W., 2011. Threshold effect and financial intermediation in economic development. Economics Bulletin 31(1), 342-357.

Ball, R., 2001. Infrastructure Requirements for an Economically Efficient System of Public Financial Reporting and Disclosure. Brookings-Wharton Papers on Financial Services, 127-169.

Baltagi, B.H., 2005. Econometric Analysis of Panel Data, third ed. John Wiley \& Sons Ltd., Chichester.

Bautista, C., P. Rous, and A. Tarazi. 2009. The determinants of bank stock return's comovements in East Asia. Economics Bulletin 29 (3), 1596-1601.

Beck, T., Demirgüç-Kunt, A., 2009. Financial institutions and markets across countries and over time: Data and analysis. World Bank Policy Research Working Paper No. 4943.

Bencivenga, V.R., Smith, B.D., 1991. Financial intermediation and endogenous growth. Review of Economic Studies 58, 195-209.

Bhide, A., 1993. The hidden costs of stock market liquidity. Journal of Financial Economics 34, 31- 51 .

Blundell, R., Bond, S., 1998. Initial conditions and moment restrictions in dynamic panel data models. Journal of Econometrics 87, 115-143.

Bose, N., Cothren, R., 1997. Asymmetric information and loan contracts in a neoclassical growth model. Journal of Money, Credit, and Banking 29(4), 423-439. 
Bose, N., Cothren, R. 1996. Equilibrium loan contracts and endogenous growth in the presence of asymmetric information. Journal of Monetary Economics 38(2), 363-376.

Bushman, R. Smith, A., 2001. Financial accounting information and corporate governance. Journal of Accounting and Economics 32: 237-333.

Chan, K., Hameed, A., 2006. Stock price synchronicity and analyst coverage in emerging markets. Journal of Financial Economics 80, 115-147.

Dabla-Norris, E., Floerkemeier, H., 2007. Bank efficiency and market structure: what determines bank spreads in Armenia ?. IMF Working Paper No. 134.

Dasgupta, S., Gan, J., Gao, N., 2010. Transparency, price informativeness and stock return synchronicity: Theory and evidence. Journal of Financial and Quantitative Analysis 45(5), 11891220 .

Deidda, L., Fattouh, B., 2002. Non-linearity between finance and growth. Economic Letters 74, 339-345.

Demirgüc-Kunt, A., Laeven, L., Levine, R., 2004. Regulations, market structure, institutions and the cost of financial intermediation. Journal of Money, Credit and Banking 36 (3), 593-622.

Demirgüc-Kunt, A. Huizinga, H., 1999. Determinants of commercial bank interest margins and profitability: Some international evidence. World Bank, Working Paper WPS 1900.

Demirgüç-Kunt, A., Detagriache, E., 1999. Financial Liberalization and Financial Fragility, in Pleskovic, B., and J.E Stiglitz, ed, Annual World Bank Conference on Development Economics, Washington, DC: World Bank, 303-331.

Diamond, D.W., 1984. Financial intermediation and delegated monitoring. Review of Economic Studies 51, 393-414.

Domanski, D. 2005. Foreign banks in emerging economies: Changing players changing issues. BIS Quarterly Review, 69-81.

Durnev, A., Morck, R., Yeung, B., Zarowin, P., 2003. Does greater firm specific return variation mean more or less informed stock pricing? Journal of Accounting Research 41, 797-836.

Dreher, A., Gaston, N., Martens, P., 2008. Measuring Globalisation - Gauging its Consequences. New York, Springer.

Flannery, M. J., 1998. Using market information in prudential bank supervision: A review of the U.S. empirical evidence. Journal of Money, Credit, and Banking 3: 273-305. 
Francis, B., Hasan, I., Song, L., Yeung, B., 2012. What determines information content in bank stock price? Global Evidence. Bank of Finland Discussion Paper 16.

Furman, J., Stiglitz, 1998. Economic crises: Evidence and insights from East Asia. Brookings Papers on Economic Activity 29(2), 1-36.

Gul, A.F., Kim, J.B., Qiu, A.A., 2010. Ownership concentration, foreign shareholding, audit quality, and stock price synchronicity: Evidence from China. Journal of Financial Economics 95, $425-442$.

Huybens, E., Smith, B., 1999. Inflation, financial markets, and long-run real activity. Journal of Monetary Economics 43, 283-315.

Iannotta, G., 2004. Testing for opaqueness in the European banking industry: Evidence from bond credit ratings. Mimeo, Bocconi University.

Jin, L., Myers, S., 2006. R2 around the world: New theory and new tests. Journal of Financial Economics 79, 257-292.

Levine, R., 2005. Finance and Growth: Theory and Evidence, in: Philippe Aghion \& Steven Durlauf (ed.), Handbook of Economic Growth, edition 1, volume 1, chapter 12, pages 865-934.

Mishkin, F., 2006. How big a problem is Too Big To Fail? A review of Gary Stern and Ron Feldman's Too Big To Fail: The Hazards of Bank Bailouts. Journal of Economic Literature 44, 988-104.

Morck, R., Bernard, Y., Wayne, Y., 2000. The information content of stock markets: Why do emerging markets have synchronous stock price movements. Journal of Financial Economics 59, 215-260

Morgan, D., 2002. Rating banks: risk and uncertainty in an opaque industry. American Economic Review 92, 874-888.

Moshirian, F., 2008. Financial services in an increasingly integrated global financial market. Journal of Banking and Finance 32 (11), 2288-2292.

Naceur, S.B., Omran, M., 2011. The effects of bank regulations, competition and financial reforms on banks' performance. Emerging Markets Review 12(1), 1-20.

Naceur, S.B, Kandil, M., 2009. The impact of capital requirements on bank's cost of intermediation and profitability: The case of Egypt. Journal of Economics and Business 61, 7089. 
Piotroski, J. D., Roulstone, B. T., 2004. The influence of analysts, institutional investors and insiders on the incorporation of market, industry and firm-specific information into stock prices. The Accounting Review 79, 1119-1151.

Poghosyan, 2013. Financial intermediation costs in low income countries: The role of regulatory, institutional and macroeconomic factors. Economics Systems 37(1), 92-110.

Rajan, R., 2005. Has financial development made the world riskier? NBER Working Paper, vol. 11728.

Roll, R., 1988. R2. Journal of Finance 43, 541-566.

Sau, L., 2003. Banking, information and instability in Asia. Journal of Post Keynesian Economics 25(3), 493-513.

Stiroh, K., 2004. Diversification in banking: Is non-interest income the answer? Journal of Money, Credit and Banking 36 (5), 853-882.

Tsai, H., Chang, Y., Hsiao, P.H., 2011. What drives foreign expansion of the top 100 multinational banks? The role of credit reporting system. Journal of Banking and Finance 35, 588-605

Wagner, W., 2007. Financial development and the opacity of banks. Economics Letters 97, 6-10.

Windmeijer, F., 2005. A finite sample correction for the variance of linear efficient two-step GMM estimators. Journal of Econometrics 126, 25-51. 


\section{Appendix}

Table 1. Descriptive statistics

\begin{tabular}{lllrrrr}
\hline Variables & Observations & Definition & Mean & Std. Dev. & Min & \multicolumn{1}{c}{ Max } \\
\hline MAR & 1372 & Market-adjusted return & 0.0003 & 0.0002 & -0.0054 & 0.0285 \\
NIM & 1579 & Ratio of net interest income to total assets (\%) & 2.4309 & 1.6210 & -13.9801 & 17.3763 \\
OVER & 1581 & Ratio of overhead cost to total assets (\%) & 2.0776 & 1.4738 & 0.5902 & 15.3612 \\
RNIM & 1579 & Profitability-adjusted net interest margin (\%) & 1.9864 & 3.4270 & -63.6857 & 16.3468 \\
SYNC & 1493 & Bank stock price synchronicity & -1.3455 & 1.6990 & -8.4440 & 2.9816 \\
$E Q T A$ & 1582 & Ratio of total equity to total assets & 0.0722 & 0.0619 & 0.0010 & 0.5787 \\
LLP & 1529 & Ratio of loan loss provisions to total loans & 0.0083 & 0.0452 & -1.1935 & 0.3007 \\
LDR & 1575 & Ratio of total loans to total deposits & 0.7144 & 0.3160 & 0.0460 & 5.7180 \\
SIZE & 1582 & Logarithm of bank total assets & 9.0476 & 1.7448 & 2.1699 & 14.1715 \\
CONC & 1771 & Bank concentration ratio from 3 largest banks & 0.4726 & 0.1454 & 0.2560 & 1.0000 \\
$G D P G$ & 1771 & Growth rate of real per capita gross domestic product & 0.0433 & 0.0287 & -0.0030 & 0.1190 \\
$I N F$ & 1267 & Inflation rate & 0.0236 & 0.0353 & -0.0337 & 0.1314 \\
$G L O B A L$ & 1579 & Globalization index & 0.5763 & 0.0686 & 0.4616 & 0.8915 \\
\hline
\end{tabular}

Sources: Authors' calculation. 
Table 2. Correlation matrix of main variables.

\begin{tabular}{|c|c|c|c|c|c|c|c|c|c|c|c|c|}
\hline & NIM & OVER & $R N I M$ & $S Y N C$ & $E Q T A$ & $L L P$ & $L D R$ & $S I Z E$ & $C R 3$ & $G D P G$ & $I N F$ & $G L O B A L$ \\
\hline NIM & 1 & & & & & & & & & & & \\
\hline OVER & 0.6905 & 1 & & & & & & & & & & \\
\hline RNIM & 0.6317 & 0.4918 & 1 & & & & & & & & & \\
\hline$S Y N C$ & -0.1572 & -0.2867 & -0.1575 & & 1 & & & & & & & \\
\hline$E Q T A$ & 0.5750 & 0.5394 & 0.0608 & -0.0703 & 1 & & & & & & & \\
\hline$L L P$ & 0.0295 & -0.0861 & 0.6025 & 0.0851 & -0.2888 & 1 & & & & & & \\
\hline$L D R$ & 0.3187 & 0.2990 & -0.0373 & -0.0778 & 0.3838 & -0.4767 & 1 & & & & & \\
\hline SIZE & -0.3824 & -0.6155 & -0.3021 & 0.6332 & -0.4130 & 0.1014 & -0.1835 & 1 & & & & \\
\hline CR3 & 0.2817 & 0.2800 & 0.1982 & -0.0031 & 0.2404 & 0.0020 & 0.2466 & -0.1818 & 1 & & & \\
\hline$G D P G$ & 0.2984 & 0.2459 & 0.1332 & 0.0451 & 0.2450 & 0.0102 & -0.0674 & -0.0284 & 0.1653 & 1 & & \\
\hline$I N F$ & 0.5083 & 0.5788 & 0.3462 & -0.2018 & 0.3680 & 0.0026 & -0.0563 & -0.4491 & 0.1734 & 0.6011 & 1 & \\
\hline GLOBAL & -0.2744 & -0.3656 & -0.2361 & 0.2908 & -0.0499 & 0.0041 & 0.0107 & 0.3323 & -0.1121 & 0.0170 & -0.3082 & 1 \\
\hline
\end{tabular}

Source and notes: Authors' calculation. NIM is the ratio of net interest income to total assets. OVER is the ratio of overhead cost to total assets. RNIM is the profitability-adjusted net interest margin measured by the residual term of an OLS regression of $N I M$ on both return on assets (ROA) and return on equity ( $R O E)$. $S Y N C$ is the index of bank opacity. EQTA is the ratio of equity capital to total assets. $L L P$ is the ratio of loan loss provisions to total loans. $L D R$ is the ratio of total loans to total deposits. SIZE is the logarithm of banks' total assets. CR3 is the share of three largest banks' total assets over banking system's total assets. $G D P G$ is the gross domestic product growth rate. $I N F$ is the inflation rate. GLOBAL is the index of globalization. 
Table 3. Validity checks for $S Y N C$ as a measure of bank opacity

\begin{tabular}{|c|c|c|c|c|}
\hline & \multicolumn{2}{|c|}{ Overall banks } & \multicolumn{2}{|c|}{ Non-Japanese banks } \\
\hline & $M A R$ & $B S R$ & $M A R$ & $B S R$ \\
\hline \multirow[t]{2}{*}{$N I$} & $0.04616 * *$ & $0.06139 *$ & $0.06292 *$ & $0.0799 * *$ \\
\hline & $(0.0274)$ & $(0.03186)$ & $(0.0363)$ & $(0.0394)$ \\
\hline \multirow[t]{2}{*}{$N I * S Y N C$} & $-0.03721 * * *$ & $-0.04274 * * *$ & $-0.03294 * * *$ & $-0.0378 * * *$ \\
\hline & $(0.0075)$ & $(0.00868)$ & $(0.0099)$ & $(0.01078)$ \\
\hline \multirow[t]{2}{*}{$N I * E Q T A$} & -0.11792 & -0.17484 & -0.18684 & $-0.24431^{*}$ \\
\hline & $(0.10002)$ & $(0.11634)$ & $(0.1319)$ & $(0.14282)$ \\
\hline \multirow[t]{2}{*}{$N I * M T B V$} & -0.00561 & -0.01074 & -0.00632 & -0.00954 \\
\hline & $(0.00625)$ & $(0.00727)$ & $(0.00811)$ & $(0.00869)$ \\
\hline Adj. R-square & 0.11 & 0.27 & 0.06 & 0.36 \\
\hline Observations & 1119 & 1119 & 569 & 569 \\
\hline
\end{tabular}

Source and notes: Authors' calculation. $M A R$ is the annualized market-adjusted daily return and measured by the difference between bank stock return and total stock market return. BSR is bank stock return. NI is the ratio of net income to the market value of equity. SYNC is the measure of bank stock price synchronicity that will be expected to depict bank opacity level. EQTA is the ratio of total equity to total assets. MTBV is the market-to-book value ratio. Models are estimated using Fixed Effects regressions controlling both bank-specific and time-specific effects. 
Table 4. Opacity $(S Y N C)$ and intermediation cost in banking (NIM, OVER, RNIM)

\begin{tabular}{|c|c|c|c|c|c|c|}
\hline & \multicolumn{3}{|c|}{ Overall banks } & \multicolumn{3}{|c|}{ Non-Japanese banks } \\
\hline & NIM & OVER & $R N I M$ & NIM & OVER & RNIM \\
\hline Dependent variable (-1) & $\begin{array}{l}0.81396 * * * \\
(0.07902)\end{array}$ & $\begin{array}{l}0.62730 * * * \\
(0.14392)\end{array}$ & $\begin{array}{l}-0.02738 \\
(0.11073)\end{array}$ & $\begin{array}{l}0.81046 * * * \\
(0.09583)\end{array}$ & $\begin{array}{l}0.53809 * * * \\
(0.13895)\end{array}$ & $\begin{array}{l}-0.00233 \\
(0.11525)\end{array}$ \\
\hline$S Y N C$ & $\begin{array}{l}-0.01924 * * \\
(0.01079)\end{array}$ & $\begin{array}{l}-0.02097 \\
(0.01682)\end{array}$ & $\begin{array}{l}-0.11019 * * * \\
(0.03711)\end{array}$ & $\begin{array}{l}-0.03386 \\
(0.02523)\end{array}$ & $\begin{array}{l}-0.03961 \\
(0.03057)\end{array}$ & $\begin{array}{l}-0.21655^{* * * *} \\
(0.06071)\end{array}$ \\
\hline$E Q T A$ & $\begin{array}{l}2.52393 * \\
(1.50261)\end{array}$ & $\begin{array}{l}4.20632 * * * \\
(1.61106)\end{array}$ & $\begin{array}{l}-1.33037 \\
(3.07489)\end{array}$ & $\begin{array}{l}4.69394 * \\
(2.52605)\end{array}$ & $\begin{array}{l}4.31118 * * \\
(1.98141)\end{array}$ & $\begin{array}{l}-2.51737 \\
(2.44779)\end{array}$ \\
\hline$L L P$ & $\begin{array}{l}-0.19520 \\
(1.53360)\end{array}$ & $\begin{array}{l}3.14260 * * \\
(1.40452)\end{array}$ & $\begin{array}{l}31.28173 * * * \\
(3.96093)\end{array}$ & $\begin{array}{l}-0.34466 \\
(1.36322)\end{array}$ & $\begin{array}{l}2.76189 * * \\
(1.26917)\end{array}$ & $\begin{array}{l}27.30138 * * * \\
(2.69056)\end{array}$ \\
\hline$L D R$ & $\begin{array}{l}-0.05494 \\
(0.16472)\end{array}$ & $\begin{array}{l}0.45998 \\
(0.30250)\end{array}$ & $\begin{array}{l}1.81778 * * * \\
(0.56913)\end{array}$ & $\begin{array}{l}-0.26134 * \\
(0.13359)\end{array}$ & $\begin{array}{l}0.48503 \\
(0.43017)\end{array}$ & $\begin{array}{l}1.12108 * * * \\
(0.41463)\end{array}$ \\
\hline$S I Z E$ & $\begin{array}{l}0.01977 * * \\
(0.00945)\end{array}$ & $\begin{array}{l}-0.01758 \\
(0.01696)\end{array}$ & $\begin{array}{l}-0.03197 \\
(0.04848)\end{array}$ & $\begin{array}{l}0.05580 * * * \\
(0.01999)\end{array}$ & $\begin{array}{l}0.00823 \\
(0.03202)\end{array}$ & $\begin{array}{l}0.06756 \\
(0.05523)\end{array}$ \\
\hline$C R 3$ & $\begin{array}{l}-0.08926 \\
(0.11384)\end{array}$ & $\begin{array}{l}0.14032 \\
(0.16701)\end{array}$ & $\begin{array}{l}0.93097 * * \\
(0.40210)\end{array}$ & $\begin{array}{l}-0.16001 \\
(0.23649)\end{array}$ & $\begin{array}{l}0.13639 \\
(0.31465)\end{array}$ & $\begin{array}{l}1.18912 * \\
(0.67396)\end{array}$ \\
\hline$G D P G$ & $\begin{array}{l}0.00509 \\
(0.00684)\end{array}$ & $\begin{array}{l}-0.01329 \\
(0.00970)\end{array}$ & $\begin{array}{l}-0.03355 * \\
(0.01905)\end{array}$ & $\begin{array}{l}-0.03226 \\
(0.02389)\end{array}$ & $\begin{array}{l}-0.04406 \\
(0.03124)\end{array}$ & $\begin{array}{l}-0.12403 * * \\
(0.05021)\end{array}$ \\
\hline INF & $\begin{array}{l}0.03237 * * \\
(0.01271)\end{array}$ & $\begin{array}{l}0.04026 \\
(0.02540)\end{array}$ & $\begin{array}{l}0.16034 * * * \\
(0.02957)\end{array}$ & $\begin{array}{l}0.01519 \\
(0.01465)\end{array}$ & $\begin{array}{l}0.05722 * * \\
(0.02503)\end{array}$ & $\begin{array}{l}0.14644 * * * \\
(0.03752)\end{array}$ \\
\hline $\begin{array}{l}\text { Observations } \\
p \text {-value for } \mathrm{AR}(1) \text { test } \\
p \text {-value for } \mathrm{AR}(2) \text { test } \\
p \text {-value for Hansen-J test }\end{array}$ & $\begin{array}{l}868 \\
0.020 \\
0.105 \\
0.099 \\
\end{array}$ & $\begin{array}{l}870 \\
0.007 \\
0.818 \\
0.047 \\
\end{array}$ & $\begin{array}{l}868 \\
0.043 \\
0.148 \\
0.095 \\
\end{array}$ & $\begin{array}{l}371 \\
0.001 \\
0.092 \\
0.064 \\
\end{array}$ & $\begin{array}{l}371 \\
0.016 \\
0.991 \\
0.076 \\
\end{array}$ & $\begin{array}{l}371 \\
0.078 \\
0.192 \\
0.085 \\
\end{array}$ \\
\hline
\end{tabular}

Source and notes: Authors' calculation. The definition of variables follows Table 1. Dynamic panel data models use the two-step GMM dynamic panel estimators with Windmeijer's robust finite sample correction, taking into account the orthogonal deviation transformations of instruments. Dynamic panel data models are valid if $A R(2)$ test and Hansen-J test are not rejected. Standard errors are in parentheses. ***, **, * indicate significance at the $1 \%$, 5\% and $10 \%$ levels, respectively. 
Table 5. Opacity $(S Y N C)$, globalization $(G L O B A L)$ and intermediation cost in banking (NIM, RNIM, OVER).

\begin{tabular}{|c|c|c|c|c|c|c|}
\hline & \multicolumn{3}{|c|}{ Overall banks } & \multicolumn{3}{|c|}{ Non-Japanese banks } \\
\hline & NIM & OVER & RNIM & NIM & OVER & RNIM \\
\hline \multirow[t]{2}{*}{ Dependent variable (-1) } & $0.78234 * * *$ & $0.66376 * * *$ & -0.07908 & $0.71845 * * *$ & $0.52442 * * *$ & -0.06684 \\
\hline & $(0.05572)$ & $(0.13551)$ & $(0.07475)$ & $(0.04973)$ & $(0.14015)$ & $(0.08895)$ \\
\hline \multirow[t]{2}{*}{$S Y N C$} & $-0.28793 * *$ & $-0.34998 *$ & -0.48131 & $-0.81305 * * *$ & $-0.97318 * *$ & -0.33359 \\
\hline & $(0.13761)$ & $(0.20284)$ & $(0.52962)$ & $(0.24154)$ & $(0.46122)$ & $(0.74913)$ \\
\hline \multirow[t]{2}{*}{$S Y N C * G L O B A L$} & $0.43282 * *$ & $0.55185^{*}$ & 0.63795 & $1.24290 * * *$ & $1.60860 * *$ & 0.26884 \\
\hline & $(0.22515)$ & $(0.32012)$ & $(0.85905)$ & $(0.40766)$ & $(0.79917)$ & $(1.23997)$ \\
\hline \multirow[t]{2}{*}{$G L O B A L$} & -0.48125 & 0.16337 & 0.92209 & $-1.88305 * * *$ & 0.10697 & -0.60559 \\
\hline & $(0.36574)$ & $(0.42748)$ & $(1.18504)$ & $(0.65818)$ & $(1.06811)$ & $(1.72896)$ \\
\hline \multirow[t]{2}{*}{$E Q T A$} & $3.17287 * *$ & $3.90234 * *$ & -1.97567 & $7.60615 * * *$ & $3.97179 * *$ & -2.47059 \\
\hline & $(1.44350)$ & $(1.54246)$ & $(3.89122)$ & $(2.13834)$ & $(1.71977)$ & $(2.90629)$ \\
\hline \multirow{2}{*}{$L L P$} & 0.56651 & $3.18000 * * *$ & $28.40958 * * *$ & 1.12616 & $2.45650 * * *$ & $25.34682 * * *$ \\
\hline & $(1.48654)$ & $(1.21313)$ & $(4.72982)$ & $(1.21457)$ & $(0.90546)$ & $(2.07790)$ \\
\hline \multirow[t]{2}{*}{$L D R$} & 0.04490 & $0.44378 *$ & $1.53951 * *$ & -0.18739 & 0.46569 & $1.11349 * * *$ \\
\hline & $(0.17977)$ & $(0.23954)$ & $(0.77750)$ & $(0.14479)$ & $(0.31697)$ & $(0.39559)$ \\
\hline \multirow[t]{2}{*}{$S I Z E$} & $0.04185 *$ & -0.03155 & -0.06647 & $0.18418 * * *$ & 0.01440 & 0.11843 \\
\hline & $(0.02359)$ & $(0.02355)$ & $(0.04689)$ & $(0.04635)$ & $(0.06431)$ & $(0.10951)$ \\
\hline \multirow[t]{2}{*}{$C R 3$} & -0.06514 & 0.18972 & $1.13712 * *$ & 0.01079 & 0.35228 & 1.55623 \\
\hline & $(0.11760)$ & $(0.17397)$ & $(0.49730)$ & $(0.26825)$ & $(0.41161)$ & $(0.96457)$ \\
\hline \multirow[t]{2}{*}{$G D P G$} & 0.01334 & -0.00365 & -0.02780 & $-0.05292 *$ & -0.04933 & $-0.13810 * *$ \\
\hline & $(0.00889)$ & $(0.00753)$ & $(0.01877)$ & $(0.02714)$ & $(0.03870)$ & $(0.06213)$ \\
\hline \multirow[t]{2}{*}{$I N F$} & $0.03108 * *$ & 0.02591 & $0.16752 * * *$ & 0.00211 & $0.04916 * *$ & $0.16779 * * *$ \\
\hline & $(0.01488)$ & $(0.01930)$ & $(0.03450)$ & $(0.01702)$ & $(0.02065)$ & $(0.03797)$ \\
\hline Observations & 805 & 807 & 805 & 308 & 308 & 308 \\
\hline$p$-value for $\mathrm{AR}(1)$ test & 0.028 & 0.034 & 0.072 & 0.000 & 0.062 & 0.119 \\
\hline$p$-value for $\mathrm{AR}(2)$ test & 0.093 & 0.973 & 0.101 & 0.103 & 0.829 & 0.173 \\
\hline$p$-value for Hansen-J test & 0.144 & 0.102 & 0.120 & 0.300 & 0.089 & 0.290 \\
\hline
\end{tabular}

Source and note: Authors' calculation. The definition of variables follows Table 1. Dynamic panel data models use the two-step GMM dynamic panel estimators with Windmeijer's robust finite sample correction, taking into account the orthogonal deviation transformations of instruments. Dynamic panel data models are valid if $A R(2)$ test and Hansen-J test are not rejected. Standard errors are in parentheses. $* * *, * *, *$ indicate significance at the $1 \%, 5 \%$ and $10 \%$ levels, respectively. 